\title{
Correction to: Hyperglycemia at admission, comorbidities, and in-hospital mortality in elderly patients hospitalized in internal medicine wards: data from the RePoSI Registry
}

\author{
Salvatore Corrao ${ }^{1,2}$ (D) Alessandro Nobili ${ }^{3} \cdot$ Giuseppe Natoli $^{1} \cdot$ Pier Mannuccio Mannucci $^{4} \cdot$ Francesco Perticone $^{5}$. \\ Antonello Pietrangelo ${ }^{6}$. Christiano Argano ${ }^{1}$. on behalf of the REPOSI Investigators
}

Published online: 17 June 2021

(c) The Author(s) 2021

\section{Correction to: Acta Diabetologica https://doi.org/10.1007/s00592-021-01716-8}

Authors would like to update the list of Reposi Investigators as collaborators and update "on behalf of the RePoSi Collaborators" to the end of authors list.

The original article has been corrected.

Open Access This article is licensed under a Creative Commons Attribution 4.0 International License, which permits use, sharing, adaptation, distribution and reproduction in any medium or format, as long as you give appropriate credit to the original author(s) and the source, provide a link to the Creative Commons licence, and indicate if changes were made. The images or other third party material in this article are included in the article's Creative Commons licence, unless indicated

The original article can be found online at https://doi.org/10.1007/ s00592-021-01716-8.

Salvatore Corrao

s.corrao@tiscali.it

1 Department of Internal Medicine, UOC Medicina Interna

2 iGR, National Relevance Hospital Trust, ARNAS

Civico, Di Cristina e Benfratelli, Piazza Nicola Leotta,

4 - 90127 Palermo, Italy

2 Biomedical Department of Internal Medicine and Medical Specialties (DiBiMIS), University of Palermo, Palermo, Italy

3 Department of Neuroscience, IRCCS Istituto Di Ricerche Farmacologiche Mario Negri, Milan, Italy

4 Scientific Direction, IRCCS Foundation Maggiore Hospital Policlinico, Milan, Italy

5 Department of Medical and Surgical Sciences, University Magna Graecia of Catanzaro, Catanzaro, Italy

6 Department of Internal Medicine II, CenterforHemochromatosis, University of Modena and Reggio Emilia Policlinico, Modena, Italy otherwise in a credit line to the material. If material is not included in the article's Creative Commons licence and your intended use is not permitted by statutory regulation or exceeds the permitted use, you will need to obtain permission directly from the copyright holder. To view a copy of this licence, visit http://creativecommons.org/licenses/by/4.0/.

Publisher's Note Springer Nature remains neutral with regard to jurisdictional claims in published maps and institutional affiliations. 